\title{
‘Ownness created a new freedom’: Max Stirner’s alternative concept of liberty
}

\author{
By Saul Newman
}

Freedom, that most familiar of concepts in political theory, strikes us today as ever more ambiguous and opaque. While freedom has for a long time been the ideological emblem of the liberal capitalist West, it seems increasingly difficult to identify with any real clarity or certainty. Its meaning has been contorted by the rationality of neoliberalism, which offers us only a very narrow notion of economic freedom while, as Foucault saw it, governing us through our own liberty. Moreover, freedom has become absolutely hinged to the ideology of security now omnipresent in liberal societies. If we add to this a consideration of the innumerable daily instances where, in contemporary societies, freedom is constrained and curtailed by over-zealous law-makers, judiciaries, police and other state institutions and private corporations, not to mention the lack of economic 'liberty’ experienced by the majority of the dispossessed around the world, we are tempted to say that the concept of freedom finds itself in a dead-end. That indeed was the conclusion reached in the midnineteenth century by the German philosopher, Max Stirner, who argued that the discourse of freedom, in its liberal and republic forms, was already exhausted. The problem with the standard notions of freedom was that they were dependent on certain external conditions and institutions like the bourgeois state, or on the fulfilment of some promise of revolutionary emancipation; they thus reduced freedom to kind of spectral ideal that always concealed deeper forms of domination. According to Stirner, if the extent of freedom was prescribed and determined by external conditions and standards - whether normative ideals, institutions, or even the actions of others - then one ended up disempowering the individual and robbing her of her own capacities for freedom. Such were the limits of the concept of freedom that 
Stirner proposed an alternative notion of ownness, by which he intended a radical understanding of autonomy and self-ownership.

The paper will explore this idiosyncratic notion of ownness. My claim is that ownness should be understood as an alternative to more familiar concepts of negative and positive freedom, as well as offering a more effective answer to the problem of domination that is the concern of republican theory. The paper will start with the experience of freedom within contemporary neoliberal societies, where it becomes the mode by which we are governed and an ideal to which the individual is sacrificed - a problem Stirner essentially foresaw in the emergent liberal societies of the nineteenth century. I will then explore Stirner's alternative proposal of ownness as a response to this problem: ownness is a form of freedom that is not dependent on external factors but is, rather, the ontological condition of the subject. The next section will be devoted to an elaboration of this theory of ownness, showing how it goes beyond more familiar analytical paradigms of negative freedom and republican nondomination. Moreover, while his refusal of the state and its laws as a guarantor of freedom bears some affinity with anarchism, in rejecting all social collectives as alienating and oppressive abstractions, and in affirming property as central to autonomy, Stirner also exceeds the ideological terrain of anarchism, putting forward instead a radical form of individualism and self-possession. At the same time, I seek to distinguish this from the more familiar notion of positive freedom as 'self-mastery', which, as Stirner shows, requires that the individual be sacrificed to some higher moral and rational ideal. In promoting instead self-defining, self-constituting and 'egoistic' forms of subjectivity outside of any prescribed standard or norm, Stirner's concept of ownness, I argue, provides a more effective antidote to the bind that freedom currently finds itself within.

\section{The problem of freedom under neoliberalism}


In his lectures at the College de France in 1978-9, organised under the slightly misleading title, The Birth of Biopolitics, Michel Foucault explored, with astonishing prescience, the emergence of neoliberalism as a new form of governmental reason, or rather a new version of the liberal art of government, which had started to pervade North American and European societies. Rather than seeing liberalism in more familiar terms as an ideology of individual rights and freedoms, Foucault insisted that it should primarily be understood as a way of governing individuals according to the rationality of the market. In this sense, freedom did not mark the degree to which we are unconstrained. Rather, freedom - essentially reduced to market freedom - becomes the very mode by which we are governed, the threshold upon which our actions are 'conducted’ and our economic interests secured. For Foucault, 'liberalism must produce freedom, but this very act entails the establishment of limitations, controls, forms of coercion, and obligations relying on threats...' (2008: 64). Neoliberalism should be seen as an extension and radicalisation of this logic in the sense that it seeks to economize every sphere of life. So far from being the principle of laissez faire, neoliberalism actually implies more intensive forms of state intervention and regulation aimed at remaking society and the economy in the image of the market (137). This new mode of government penetrates into the very soul of the individual, who is remade as homo economicus - an 'entrepreneur of himself, being for himself his own capital.' (226) As all human relations under neoliberalism become economised and a potential source of capital, and as the market becomes the ultimate site of legitimacy and 'veridiction' (32), the individual is turned into a 'permanent and multiple enterprise' inserted into a network of other enterprises such as family, household, insurance and retirement (241).

While Foucault sees the homo economicus of liberal thought as limiting the traditional power of the sovereign even more profoundly than homo juridicus - the man of rights, alongside which he emerges - we must not suppose that he is a free subject. Not only is his formal 
freedom always shadowed by mechanisms of control and securitization, but in seeing himself as his own enterprise, he becomes permanently accountable to the market norms and social processes which produce him. Indeed, as Wendy Brown argues in her recent analysis of neoliberal governing power and its deracinating effect on law, public institutions and the democratic space, homo economicus is not so much a creature of economic interests but, rather, as a unit of responsibilized human capital, a 'sacrificial citizen', routinely called upon to sacrifice his own interests in the name of obscure market forces and economic exigencies over which he has no control, as we have seen in recent times with programmes of austerity:

Thus, while neoliberalism formally promises to liberate the citizen from the state, from politics, and even from concern with the social, practically, it integrates both state and citizenship into serving the economy and morally fuses hyperbolic selfreliance with readiness to be sacrificed (Brown 2015: 212).

\section{Stirner's critique of liberal freedom}

Max Stirner also recognised this sacrificial dimension in liberal societies. In terms which seem to prefigure Foucault, Stirner sees what he calls political liberalism as a governing rationality which, while purporting to protect the individual from sovereign power and religious authority through a discourse of rights and freedoms, essentially incorporates the individual into the state: 'Political liberty means that the polis, the state is free... It does not mean my liberty, but the liberty of a power that rules and subjugates me.' (Stirner 1995: 142) The freedom promised by liberalism is the freedom of the state, not the freedom of the individual. However, this was part of a broader problem - a sacrificial element at work in all modern societies. In his only major work, The Ego and Its Own (Der Einzige und sein Eigentum, better translated as 'The Unique and His Property', 1845) Stirner argued that the humanist and rationalist philosophy prevalent at the time - particularly that of his 
contemporary, Ludwig Feuerbach - was simply Christianity reinvented in a new secular guise, where the individual is sacrificed no longer on the altar of God, but now of Man. As Stirner put it, “'Man’ is the God of today, and fear of man has taken the place of the old fear of God.' (1995: 165) The individual in this new secular and humanist age is plagued by 'fixed ideas', moral and rational ideals which he is expected to conform to. (43) Humanism, and its political expression in liberalism, republicanism and even socialism, is a profoundly sacrificial ideology in which individuals, in their uniqueness and singularity, are coercively absorbed into abstract, alienating generalities, namely Humanity, Society and the State.

Of course, it is important to acknowledge that when Stirner condemns the state as an instrument of domination, he has in mind the Hegelian conception of the State as the embodiment of a totalising rational and ethical 'spirit' which represented the 'march of God on Earth', and which the individual must serve (97-8). This is of course a very different to the neoliberal state that I have in my sights, where the mechanism of control is more subtle and pervasive and relies on a certain 'self-government' of the individual. Also, the element of sacrifice that can be identified in both of them nevertheless requires a sacrifice to different things, to the idealised moral community into which the individual must be incorporated in the case of the Hegelian state, and to the abstract rationality of the market, in the case of the neoliberal state. Moreover, Stirner’s specific understanding of the State - engaged as he was in a polemic against his Left Hegelian contemporaries like Feuerbach and Bruno Bauer leads him to conflate liberalism and republicanism and deploy categorisations of freedom which do not map easily onto our more familiar understanding of negative freedom, and republican non-domination, between which there is an important distinction to be made. The liberal approach to the state, which generally seeks to limit intervention - or at least regard state intervention as the negative measure of freedom - and the republican approach, which might allow intervention (provided it was non-arbitrary) - or at least see intervention per se 
as less of a determinant of freedom - are indeed very different. There is always the danger of anachronism or conceptual misunderstanding in applying Stirner's view of the state to contemporary debates in political theory over how freedom should be understood. However, my point here is that Stirner's critique of the concept of freedom, as an illusory abstraction that marks a deeper domination, reveals something about the dead end freedom finds itself in today, which, I argue, the current analytical categories are unable to retrieve. The neoliberal trap, whereby freedom itself becomes a threshold of subjectification, domination and sacrifice, was similar to the problem that Stirner was dealing with in his time; and it is something that cannot be adequately grasped, let alone resisted, through either liberal or republican approaches.

Stirner's answer to this, as we shall see, lay in the abandonment of the goal of freedom - a concept that was tarnished by liberal ideology and Christian theology - or rather its transformation into ownness, a kind of egoistic form of self-ownership: 'Must we then, because freedom betrays itself as a Christian idea, give it up? No, nothing is to be lost, freedom no more than the rest; but it is to become our own, and in the form of freedom it cannot.' (143) The value of Stirner's critique of freedom lies in enabling us to rethink the concept in response to neoliberalism. In my view, neoliberalism is more effectively contested, not on the grounds of equality, nor from the perspective of democracy, as Wendy Brown does (see 2015), but rather on its own terms - those of individual freedom. Stirner not only reveals the inadequacy of liberal (and neoliberal) accounts of freedom, but presents a far more radical alternative to them, one that serves, as we shall see, as a point of resistance to dominant liberal and neoliberal modes of subjectification. It may seem odd here to look to a thinker at times interpreted, wrongly in my view, as promoting a kind of free-market form of self-interest (see Marshall 2008: 232; Schmitt and van der Walt 2009: 52). Does it not seem perverse to choose 'egoism' as basis for a critique of neoliberal societies? However, Stirner 
would consider the individual freedom proclaimed by neoliberalism as a kind of trap - a logic that reduces the individual to an infinite conformability with the norms of society. In this sense, the problem with neoliberalism is not too much egoism, but too little. Stirner's philosophy of ownness, individual autonomy and proprietorship are utterly incompatible with liberal or neoliberal ‘possessive individualism'. His egoist is simply not the same thing as homo economicus.

\section{From Freedom to Ownness}

We have seen in the previous section the way that, for Stirner, freedom has been perverted into a new form of domination. The problem is that in turning freedom into an ideal to be attained, and in tying it to a certain institutional regime or form of society, one essentially alienates freedom from the individual. This is why, according to Stirner, freedom appears to us moderns increasingly as an empty, hollow dream, a mystification. By contrast, ownness, a radical form of self-ownership, is much more tangible to the individual. Ownness may be seen as a form of freedom that is no longer dependent on external conditions, whether these are the actions of others, or one's conformity with what Stirner sees as externally imposed moral and rational ideal (which one is forced to internalise), or the presence of regime of law that supposedly guarantees non-domination. Such conditions remove the capacity for freedom from real individuals. Behind every universal ideal of freedom there lurks, according to Stirner, a new form of domination, as it is always someone's particular idea of freedom that is being imposed upon the world: 'The craving for a particular freedom always includes the purpose of a new dominion' (145; emphasis in the original, and in all quotes henceforth). This is why Stirner is suspicious of the idea of revolutionary emancipation, or indeed of any kind of emancipation other than self-emancipation: 'The man who is set free is nothing but a freed man, a libertinus, a dog dragging a piece of chain with him; he is an unfree man in the garment of freedom, like the ass in the lion's skin.' (152) Rather, it is up to the individual to 
liberate herself. Ownness seeks to make freedom real by placing it back within the grasp of real individuals who are free to create their own singular path of freedom.

There is a deeper problem with emancipation. For Stirner, there is in a sense nothing to emancipate. The individual is already free in an ontological sense, because she has ownness, because she is her own. The 'owner', for Stirner, is 'free-born, the man free to begin with', whereas the free man is simply a dreamer chasing after illusions. The former

is originally free, because he recognises nothing but himself; he does not to free himself first, because at the start he rejects everything outside himself, because he prizes nothing more than himself, rates nothing higher, because, in short, he starts from himself and 'comes to himself' (149)

Unlike the sacrificial neoliberal subject, and unlike the liberal and republican subject who, as Stirner perceived in his own time, sacrificed themselves to another ideal of freedom - the free state - the owner takes himself as his own axiom and regards freedom not as an external goal to be obtained, but rather as his permanent ontological condition. Freedom, for Stirner, should be a question of self-empowerment and the recognition and affirmation of one's own self as the condition and measure of freedom, rather than any external condition.

\section{Ownness and negative freedom}

In distinguishing between ownness and more standard conceptions of freedom, the advantages of the former become evident. Stirner points out the limitations, firstly, with liberal negative freedom. While negative freedom gives you freedom from something - from external interference and constraints - it also leaves you with nothing. It is, thus, for Stirner, an empty experience: 'And, if you become free from everything, you would no longer have anything; for freedom is empty of substance' (1995: 141). While one can become free from many things, one might actually want to have something, to possess, consume and enjoy it. 
The other problem with negative freedom is that it claims to be quantifiable, so that one always has more or less, depending on the extent to which one is or is not constrained or interfered with, or one's opportunities to act are or are not limited by the actions of others. The desire for freedom from constraint is thus always contradictory, for Stirner: some people want freedom from some things and not from others, and thus there is always a disagreement over how much freedom people should have or what kinds of things they should be free to do. Some want greater freedom of religion, but not necessarily freedom from religion; others want more political freedoms, by which they mean freedom from absolutism and arbitrariness, but not freedom from the state (144-145). However, for Stirner, this understanding of freedom cheapens and diminishes the concept, turning it into a partial, limited thing: 'Freedom you all want, for want freedom. Why do you haggle over a more or less? Freedom can only be the whole of freedom; a piece of freedom is not freedom' (1995: 144). Yet, if one were to pursue the whole of freedom - 'freedom from everything' - this would be like chasing after an illusion. So the notion of freedom ends up in a series of contradictions.

The question of 'more or less' (freedom) is central to liberal reasoning, according to negative libertarian Ian Carter, who argues for a concept of 'overall' freedom that has a non-specific value - freedom ‘as such'1: ‘If freedom is “non-specifically valuable”, then we attach value to our freedom not only because of the specific things it allows us to do, but also because of the mere fact of our having freedom.' (1999: 34) Moreover, for Carter, this non-specific value can be quantitatively measured through various metrics (see 269-287; see also Kramer 2003: 7) Yet, for Stirner, the claim that freedom can be objectively quantified does not make it any less of a spectre; it does nothing to place it more firmly within the grasp of individuals. The problem lies in the assumption that there is a universal standard of measurement that can be commonly agreed and recognised. For Stirner, this would be another instance in which an 
abstraction is imposed upon individuals, whose experiences of freedom might be entirely different. The advantage of ownness, in contrast, is that it takes only the self and its interests into account; in this sense, it is a more tangible and concrete way of approaching freedom because it respects the absolute singularity of the individual as his own unique standard of freedom. Ownness is an experience of freedom that starts from the concrete actuality and singularity of the individual and his or her experience, capacity and power. While this no doubt makes freedom difficult to quantify as an overall concept, for Stirner, to assume that this is even possible is to turn freedom into an alienating abstraction.

We should be clear, however, that Stirner's differences with the analytical approach of the negative libertarians, does not mean that he would subscribe to the view of freedom as a normative condition either. ${ }^{2}$ Needless to say, Stirner questions the idea that freedom is a moral good (he does course does he say it is morally bad either). He avoids prescriptive statements about how much freedom one should have or what sorts of freedoms one should have; and he would eschew claims that one is only free insofar as one acts in a certain way or that 'legitimate' constraints are really no constraint at all. He does not qualitatively evaluate different types of freedoms. While Stirner would share the view of William Connolly that freedom is an 'essentially contested', as opposed to neutral, concept and therefore bound up with power, discourse and competing interests, he would at the same time remain sceptical of the claim that freedom should be conditioned by a normative ideal of autonomy (see Connolly 1993: 140-173). From the perspective of Stirner's nominalism, freedom has no independent value; it can only be determined by the self and its particular interests. Behind every demand for liberty there is not some universal idea, but rather only self-interest. Thus, if freedom always presupposes that which is good for oneself, rather than a social or moral ideal, the self can be the only real measure of freedom: 'Why will you not take courage to 
make yourselves really the central point and the main thing altogether? Why grasp in the air at freedom, your dream?' (146)

For Stirner, then, it is better to have ownness:

What a difference between freedom and ownness! One can get rid of a great many things, not from everything... Ownness, on the contrary, is my whole being and existence, it is I myself. I am free from what I am rid of, owner of what I have in my power or what I control. My own I am at all times and under all circumstances, if I know how to have myself and do not throw myself away on others. (143)

Ownness is therefore a much more tangible and real form of freedom. It is more affirmative than negative freedom in the sense that it is an expression of the individual's own power and capacity. It is something that the individual has as part of her very existence, regardless of the external constraints one finds oneself under. By contrast, negative freedom insofar as it is dependent upon the degree to which one is constrained or interfered with, is ultimately limited and flimsy.

\section{Ownness and republican freedom}

Ownness also differs substantially from the theory of freedom proposed as an alternative to liberal negative freedom - the republican theory of freedom as non-domination (see Laborde 2008; Bellamy 2011). Leaving aside the claims of Carter (237-245) and Kramer (2008: 3157) that the republican concept of non-domination of freedom adds little to theory of negative freedom, thinkers such as Quentin Skinner and Phillip Pettit have argued that the republican or neo-Roman tradition of political thought isolated a specific understanding of liberty that went beyond the liberal idea of freedom from constraints and interference and referred to a more general notion of security of freedom, or what Pettit refers to as 'resilient noninterference' (Pettit 1997: 24). The chief problem for the proponent of negative liberty is 
interference as such, whereas the chief problem for the proponent of republican liberty is arbitrary interference. In other words, for the republican, what limits the liberty of an individual is not that she is interfered with by another; there might be many forms interference which are either to the benefit of the individual, or which are sanctioned by a stable and democratically agreed system of laws. Rather, what does unduly limit the freedom is living under an arbitrary relationship of power in which the threat of interference and constraint, while not always, or ever, actualised, is nevertheless always hanging over her head. This is what counts as domination for the republican.

This problem is vividly illustrated by the example of the slave who lives under the control of a master who does not constrain or unduly interfere with the slave's day to day activities, whether out of benevolence or inattentiveness. For the proponent of negative freedom, the slave - insofar as he is not being directly interfered with - is, strictly speaking, free; whereas for the advocate of republican freedom, the slave is unfree because he lives under an unequal and arbitrary form of power that renders him vulnerable to the whims of his master. The slave never knows when his master might, for whatever reason, start to interfere with and constrain him, and there are no guarantees that he will not do so. The slave enjoys no security of liberty. Rather than look another individual in the eye as a free and equal man, the slave has to use various strategies of cunning, deception and flattery to appease his master, to keep him from exerting his arbitrary rule over him. Thus, for Pettit, then, 'Domination, as I understand it here, is exemplified by the relationship of master to slave or master to servant. Such a relationship means, at the limit, that the dominating party can interfere on an arbitrary basis with the choices of the dominated.' (1997: 22) Similarly, for Skinner, in his historical reconstruction of the neo-Roman tradition, freedom for the republican means living in a free state, a state governed by a stable system of laws which are clearly understood and consented to; whereas 'if you live under any form of government that allows for the exercise of 
prerogative or discretionary powers outside the law, you will already be living as a slave.' (Skinner 1998: 70) So, there is an important difference, for republicans, between interference and domination. One can be dominated in non-interfering ways, as the above example suggests; and one can be interfered with in non-dominating ways. One can have, as Pettit puts it, a non-interfering master, just as one can have a non-mastering interferer (1997: 23).

There are, however, two key problems with this republican theory of liberty, which Stirner's theory of ownness highlights. The first concerns the way that this notion of non-domination would seem to countenance, even endorse, many forms of interference and constraint on individuals' actions, provided that these were non-arbitrary and 'tracked their interests', as Pettit would say. For Pettit, republican freedom 'is consistent, unlike freedom as noninterference, with a high level of non-arbitrary interference of the sort that a suitable system of law might impose’ (1997: 84). Of course, we can point to many examples of state intervention, for instance, that are non-dominating and which would seem to reflect the interests those being interfered with - which may indeed improve their situation and enhance their independence: the provision of welfare to the poor; the protection of vulnerable people and minorities from abuse and discrimination; laws against domestic violence; labour laws that prevent excessive exploitation and enable collective bargaining, and so on. Indeed, Pettit sees republican theory as protecting people, particularly workers, from corporate domination and excessive exploitation (140-143) and even defending the democratic space against the undue influence of the economic powerful (194). Notwithstanding some of the social protections potentially afforded by a republican state, ${ }^{3}$ I see this as insufficient to cope with the problem of neoliberal subjectification, which, as Foucault has shown, involves an infinitesimal government of the individual in the name of freedom. Foucault has taught us to be aware of the unequal power relations, the seemingly benign forms of disciplinary and biopolitical domination - the whole panoply of interventions by social workers, psychiatrists, 
doctors and teachers - behind the calm veneer of a liberal society. Republican theory would also allow more directly coercive forms of intervention, provided, of course, that this was non-arbitrary and regulated by sufficient constitutional arrangements. For the republican, the decisive factor here between domination and legitimate interference is non-arbitrariness rather than the extent or degree of coerciveness of the interference itself. Non-arbitrariness and constitutional legality would thus seem to authorise potentially a whole range of coercive and punitive measures on the part of the state. The problem relates in part to the vagueness of the notion of 'tracking interests', which Pettit uses to rationalise what he sees as nondominating interference: this would seem to refer not, or not entirely, to the interests of the individual affected - for it would be ludicrous to say, for instance, that the punishment inflicted upon a person by the state was at the same time reflecting her interests - but rather to some general or common interest that the individual is said to share, even if this might at times conflict with her own personal interest. The person who is punished by the law might not appreciate his or her punishment, but she still has an interest in living under the rule of law, rather than under arbitrary authority. However, there is a danger in proclaiming a general interest that transcends those of individuals. For Stirner, any notion of a higher community ideal or interest ends up sacrificing the interests of real individuals. So my point is that while republicanism has revealed the problem of domination, particularly the anticipatory behaviours it induces in individuals, in its fixation on preventing the exercise of arbitrary power through the rule of law, it has left it itself largely blind to, or at least insufficiently concerned with, the dominating effects of non-arbitrary power.

This point is reflected in Stirner's critique of his contemporary, Bruno Bauer, whose revolutionary republicanism and Hegelianism Stirner’s notion of ownness specifically contested (see De Ridder 2008: 285-29). Bauer sought a kind of new universal form of politics and society that would guarantee individual rights and political equality, while at the 
same time resisting the particularism and egoism associated with economic liberalism and the old order (see Moggach 2003). From Stirner’s side, however, the revolutionary universalism of Bauer promised the emancipation of Man as an abstract ideal, while at the same time subordinating the concrete individual to external institutions like the constitutional state and its laws. Thus, the republican revolt against 'arbitrariness' and dependency on the will of another leads to another kind of domination - that of the law itself: 'For one is rid of orders indeed, and "no one has any business to give us orders", but one has become so much the more submissive to the - law. One is enthralled now in due legal form.' (Stirner 1995: 98) The republican state claims that it is protecting the individual from the type of arbitrary and absolutist power of the old regime by establishing a constitutional system that guarantees rights and freedoms. However, in freeing the individual from this arbitrary form of authority, it simply enslaves the individual to the state and its laws: 'Republicans in their broad freedom, do they not becomes servants of the law?' (142) Rather than the state guaranteeing non-domination by ruling out arbitrariness, it simply sets itself up as our new master.

\section{The ownness of the slave}

This brings us to the second, more fundamental, problem with republicanism. Similarly to negative freedom, the republican conception also ends up disempowering the individual by sacrificing his freedom to an abstract ideal determined entirely by external factors. In considering the problem of domination, Stirner reflects on the master/slave relationship, which, for republicans, was the very epitome of unfreedom. Stirner seeks to show, by contrast, that while the slave may not have much freedom, he nevertheless has ownness, the one thing his master cannot take away from him:

To be free is something that I cannot truly will, because I cannot make it, cannot create it: I can only wish it and - aspire toward it, for it remains an ideal, a spook. The fetters 
of reality cut the sharpest welts in my flesh every moment. But my own I remain. Given up as serf to a master, I think only of myself and my advantage; his blows strike me indeed, I am not free from them; but I endure them only for my benefit, perhaps in order to deceive him and make him secure by the semblance of patience, or, again, not to draw worse upon myself by obstinate resistance. But, as I keep my eye on myself and my selfishness, I take by the forelock the first good opportunity to trample the slaveholder into the dust. (143)

The situation Stirner describes is one in which the subject has very little or no freedom, on either the republican and negative accounts. ${ }^{4}$ The individual slave is both physically interfered with, as well as living under an entirely arbitrary form of mastery that - whether he was or was not directly interfered with - would nevertheless render him unfree (at least according to republican theory). To simply evaluate the slave's situation using the terminology of freedom would only confirm his lack of it and would not get him very far. Yet, according to Stirner, the slave, while he may not have freedom, still has ownness or a sense of himself and his interests - and it is this that serves as the basis for his act of selfliberation. There is, in other words, something that precedes freedom, something more elemental, which affirms the self even in the absence of freedom and in the most oppressive of circumstances, and which acts as the spark that ignites the act of resistance. Egoism or ownness - the two terms are closely associated, at times virtually interchangeable for Stirner - is ontologically primary here; it precedes freedom: 'That I then become free from him and his whip is only the consequence of my antecedent egoism.' (143) In other words, one had to have a sense of oneself - a sense of self-possession - before one could liberate oneself from a relationship of domination. The point here is that freedom simply cannot explain this act of liberation, as the slave had no freedom. Something else had to come before it, and this is the 
slave's ownness, which served as the very limit of power and the point of resistance to it. As it is deployed here, ownness is more empowering than freedom and it points to something beyond both the liberal negative and republican accounts of the concept.

Perhaps we can speak of a certain positive liberty here, a kind of internal freedom? However, Stirner makes it clear that this does adequately account for ownness: 'Here one perhaps says I was "free” even in the condition of slavery - namely "intrinsically" or "inwardly”. But "intrinsically free” is not "really free”, and "inwardly" is not "outwardly" (143). I will return to the question of ownness and positive freedom later, as there are other surface similarities that need to be explored. However, it is clear at this point that, for Stirner, ownness is something rather different to freedom - at least, it does not fit into any of the accepted categories of freedom. It refers to an egoistic sense of self or self-ownership that, as I have argued, precedes all instances of freedom and acts as their catalyst. As John Welsh (2010: 85) puts it: 'Ownness is a revelation of what the person really is. It refers to what the person really values and enjoys, and what he or she is willing to sacrifice.' So while the slave in the situation Stirner describes is not free - at least on any of the normal registers of the concept he is his own 'inwardly and outwardly.' As Stirner says: 'Under the dominion of a cruel master my body is not 'free' from torments and lashes; but it is my bones that moan under torture, my fibres that quiver under the blows, and I moan because my body moans.' (143)

\section{Ownness and resistance}

It might be useful to think of this elemental sense of self that ontologically precedes freedom, in terms of Foucault's highly suggestive notion of 'plebs'. Foucault refers to a certain 'plebian quality' that exists as the limit of power relations and serves as the ontological ground for resistance: 
But there is always something in the social body, in classes, groups and individuals themselves which in some sense escapes relations of power, something which is by no means a more or less docile or reactive primal matter, but rather a centrifugal movement, an inverse energy, a dis-charge. (1980: 134-145)

This points once again to the idea, expressed in the concept of ownness, of freedom as the ontological ground on which the subject acts, rather than as a kind of quantifiable substance strictly determined by the degree of constraint one faces. The advantage of thinking about freedom in this way is that it is more empowering to the individual; it shows that resistance is possible even in situations in which freedom is seemingly very limited. It does not neglect or 'wish away' the existence of external material constraints in some idealist sense, as Marx and Engels accused Stirner of doing in their famous critique of 'Saint Max' in The German Ideology (see 1932). Rather, it points to what can perhaps be seen as a dimension of selfabnegation or 'voluntary servitude' at the base of all power relations, the flip-side of which is a reclamation of the self, whereupon power relations are radically overturned. So, for Stirner, domination is as much a state of mind as a real, material condition, and it is our recognition of our own status as slaves, or in Hegelian terms as servants, that makes the State's domination over us possible: 'The state is not thinkable without lordship [Herrschaft] and servitude [Knechtshaft] (subjection)... He who, to hold his own, must count on the absence of will in others is a thing made by these others, as the master is a thing made by the servant. If submissiveness ceased, it would be all over with lordship.' (174-5)

We should think of ownness, then, in terms of an ethical work conducted on ourselves, so that the self may be affirmed over the external constraints and power relations that appear to hem it in. This is further made clear in Stirner’s concept of the ‘insurrection’ or ‘uprising' [Empörung], a form of radical action which is nevertheless distinct from revolution. While 
revolutions, in their social and political goal of freedom, seek to transform external conditions, the insurrection 'is not a fight against the established, since, if it prospers, the established collapses of itself; it is only a working forth of me out of the established.' (1995: 279-80). I will return to this point later when I consider ownness in relation to self-mastery and self-possession.

\section{Stirner and anarcho-republicanism}

To what extent can Stirner's theory of freedom as ownness - given that it does not fit with either liberal negative freedom or republicanism - be seen as anarchistic ${ }^{5}$ Of course, anarchists share many of Stirner’s criticisms of republicanism. According to the anarchist Mikhail Bakunin, political republicanism, a 'republic of citizens', is a religion of the state and it views liberty as only being possible within a state: 'Liberty, to a political republican, is an empty word, it is the liberty of a willing slave, a devoted victim of the State.' (1971: 118-119) What was particularly problematic about the republican emphasis on non-domination is its reliance on law. Republicans make a fetish of the idea of the rule of law. As we have seen, a stable, transparent, regular legal system becomes the guarantee of non-arbitrariness and therefore of non-domination. Pettit says: 'The parliament and the police officer, then, the judge or the prison warder, may practice non-dominating interference, provided... that a suitably constraining, constitutional arrangement works effectively.' (1997: 65) However, for anarchists, the rule of law brings with it its own domination; it violates the autonomy of the individual, interfering, as William Godwin put it, with one’s right to private judgement: “'I have deeply reflected', suppose, 'upon the nature of virtue, and am convinced that a certain proceeding is incumbent upon me. But the hangman, supported by an act of parliament, assures me I am mistaken.”’ (1985: 689) Stirner, too, recognised the essential incompatibility 
between law and individual freedom, arguing that there was indeed no real difference between law and arbitrary decree when it came to its effects upon the individual:

People are at pains to distinguish law from arbitrary orders [Befehl], from an ordinance: the former comes from a duly entitled authority. But a law over human action (ethical law, state law, etc.) is always a declaration of will, and so an order. (1995: 174)

When it comes to the individual who is in conflict with the law, the question of the law's legitimacy and non-arbitrariness is irrelevant: all she sees is a command that is contrary to her own will, a command that is backed up with coercive force. ${ }^{6}$ So, for anarchists, republicans pay insufficient attention to the domination involved in what they regard as non-dominating interference. What anarchists want is both non-domination and non-interference, or at least as little interference - especially coercive interference - as possible.

These criticisms notwithstanding, there are elements of the republican theory of nondomination that are appealing to some anarchists. Ruth Kinna and Alex Prichard seek to radicalise elements of republican theory and propose what they call a 'constitutionalism of non-domination', in opposition to alternative currents in anarchism that emphasise selfempowerment and wilfulness as a solution to the problem of domination. ${ }^{7}$ Rather than look to the self and its own capacities for freedom as a means of transforming social relationships, Kinna and Prichard propose a normative framework of non-domination by which to judge whether or the extent to which certain relations of power are arbitrary. Republican nondomination provides, they argue, 'a negative constitutional principle supportive of anarchist and other horizontal autonomous communities and groups’ (2012).

The problem with this proposal for anarchist constitutionalism, however, is that it once again makes freedom dependent on set of normative conditions and ultimately on an idealised community - one of horizontalism, reciprocity and transparent structures of power. There is 
nothing wrong with this vision per se, but my concern here is to develop - drawing on Stirner's theory of ownness - an alternative understanding of freedom grounded in the ontological power of the individual and is not dependent on external social or political conditions. Indeed, Stirner would see any such attempt to ground freedom in a project of republican or anarcho-republican constitutionalism as prescriptive, and as something that therefore takes freedom out of the hands of individuals and places it within an abstract figure of the social. While Stirner is against the state and its laws, he is also suspicious of all other forms of community and society, even those based on anarchist principles, as excessively prescriptive and disempowering for the individual. ${ }^{8}$

\section{Property and self-ownership}

One of the other key criticisms anarchists have of the republican theory of liberty is its insufficient concern with the domination involved in the concept of property (see Kinna and Prichard 2012). Of course, in earlier republican traditions, the problem of slavery was intrinsically linked with the concept property: not only the fact that one person could own another as his property, but that freedom itself, in opposition to slavery, was defined by the ability to own property. Kinna and Prichard point to the close association between notions of dominion and property, showing that property relation, under modern capitalism, simply enshrined a new form of wage-slavery. In doing so, they draw on Proudhon's excoriating attack on the concept of property: not only did property violate justice, equality and the social principle, it was, for Proudhon, a fraud, a fiction and an impossibility (see 1993). After showing that there was no legitimate basis to property, that it can be justified neither on the basis of natural right nor the right of first occupancy, nor any kind of universal consent, Proudhon demonstrates that property - in extracting profit through rent - is entirely unproductive and exists only in a parasitical and extortive relationship to labour. Property is a kind of alchemy which produces wealth for the proprietor without the need to labour, creating 
something from nothing, but in doing so, going against any principle of economic justice whereby products can only be bought by other products (1993: 168). Property leads not only to economic despotism, but also to political despotism (211). This critique could be summed up in Proudhon’s famous formulation: “"What is property?”... "It is theft.” (13)

For Stirner, however, Proudhon’s critique actually proves the inevitability of property. Indeed, the very dictum property is theft actually affirms the sanctity of property: 'Is the concept 'theft' at all possible unless one allows validity to the concept “property”?' (Stirner 1995: 90).

However, the concept of property is too hastily associated with domination here. From Stirner's perspective, property actually provides a refuge for individual autonomy: 'The politicians, thinking to abolish personal will, self-will or arbitrariness, did not observe that through property [Eigentum] our self-will [Eigenwille] gained a secure place of refuge.' Here property refers less to material possessions, and more fundamentally to a notion of selfownership or 'self-will'. Yet, this is somewhat different from the liberal or even libertarian understanding of self-ownership. Locke's famous conception of having 'Property in his own Person' (1988: 287) became the moral basis for the legitimate appropriation of external goods, enshrined by natural rights and later protected through law. By contrast, Stirner’s conception of property and self-ownership is much more 'anarchic': property is simply based on power - one’s power to possess - something that is entirely indifferent to established property rights. As with freedom, Stirner wants to desacralize and profane the concept of property - it should not be seen as a moral ideal or an institution to be respected; property is simply what we have the power to attain, and it is defined by no axiom other than that of the self. In this sense, it is very closely bound up with the idea of self-affirmation and selfempowerment central to ownness. The catechism of the egoist runs thus: 'My power is my property. My power gives me property. My power am I myself, and through it am I my 
property.' (166) Because property in Stirner's hands becomes so excessive - the entire world becomes the property of the egoist - the notion loses all stability and becomes entirely fluid. In this sense, it simply cannot be contained within a liberal or neoliberal framework of property rights. Indeed, as John Carroll argues, Stirner's reformulation of the concept of property can be seen as a rejection of the narrow doctrine of homo economicus (1974: 134144).

(Stirner's rejection the of idea of property rights finds some echo in P.. > but different)

\section{Ownness, self-mastery and positive freedom}

As I have suggested, ownness implies a form of self-possession or what might be understood as self-mastery. The owner, for Stirner, is one who not only has a sense of her own interests and a capacity for power - something that would make her a simple egoist, but not necessarily an owner - but, more importantly, has control over herself and her own desires; has possession over herself. This is what separates Stirner's sophisticated egoism from cruder accounts in which the individual merely pursues blind self-interest. ${ }^{9}$ Indeed, I would argue that Stirner's notion of ownness implies a certain ethical relationship to oneself, such that the individual is able to master her instincts, passions and desires, even her desires for external objects or her desire for power over others. The opposite of self-possession, that which threatens one's self-mastery, is a state Stirner refers to as 'possessedness', where one becomes mastered by one’s own desires and passions, rather than achieving mastery over them. The one who sacrifices himself on behalf of his selfish passions and desires for external objects is just as possessed as the one who sacrifices her desires on behalf of some obscure moral ideal. Both are ruled in their own way by a passion which is entirely one-sided and which leads to an erosion of their self-mastery: 'Their entire activity is egoistic, but it is a one-sided, unopened, narrow egoism; it is possessedness.' (70) They are both equally possessed by external objects that come to command their desires and lead to a sacrifice of 
other elements of their personality. It is not that the individual should resist passions and desires, but she should not allow herself to be controlled by them. The owner always takes a kind of distance from her own desires, such that she can master them: 'I am my own only when I am master of myself, instead of being mastered either by sensuality or by anything else (God, man, authority, law, state, church)’ (153). From Stirner’s perspective, the homo economicus of liberalism/neoliberalism is a possessed, haunted person, a subject mastered precisely by external market forces and interactions, which become internalised as desires.

Ownness would therefore seem to imply a self-discipline, such that one can master one's own desires and appetites. Indeed, freedom requires a certain kind of discipline, including an ethical discipline that one exercises over oneself in order to master and control the desires, tendencies and dependencies that otherwise lead one to being susceptible to the power of others. Without this, according to Richard Flathman (2003), there is no agency and therefore no freedom. I would suggest that Stirner, in warning of the dangers of 'possessedness', is thinking in similar terms: a certain understanding of freedom that comes through self-mastery and self-possession. And, similarly to Foucault, with his interest in the cultures of the 'care of the self' in Greek and Roman antiquity, Stirner was concerned with showing how we could become more autonomous and reclaim the self through ethical self-discipline. ${ }^{10}$

This emphasis on autonomy and self-mastery would seem at first glance to bring ownness into close proximity with positive freedom, understood in Isaiah Berlin's sense ‘being one’s own master' (1969), or in Charles Taylor's sense that freedom involves 'the exercising of control over one’s life' (2006: 143). There is certainly a parallel between Stirner's concern about the problem of 'possessedness' and Taylor's claim that freedom as an exercise concept requires that we can correctly identify our desires and 'discriminate amongst motivations' (146). However, where ownness departs from positive freedom is in its rejection of any 
higher moral or rational ideal that the self aspires to, conformity with which becomes the mark of one's freedom. There is no notion in Stirner of Berlin's two selves - the 'authentic' self that must master the lower, empirical self. There is no sense of the two strategies that Berlin speaks of: 'that of self-abnegation in order to attain independence; the second, that of self-realization or total self-identification with a specific principle or ideal in order to attain the self-same end.' (1969: 134) The idea that the self should be sacrificed, or that the individual should live up to some higher moral or rational ideal or principle, could not be further from Stirner's sensibilities. He rejects what he calls the moral freedom of thinkers like Hegel, for whom freedom lies only in devotion to a higher rational cause (1995: 95). These would simply be another kind of possessedness. What Stirner is opposed to is the expectation that we conform or live up to any particular ideal, including even that of egoism itself. All such expectations involve a sacrifice of the individual to a moral or rational abstraction. Stirner, moreover, is suspicious of the idea of a collectively realised freedom, and he would have no truck with the idea that constraints can increase freedom (see Kramer 96-7) or that one can in any sense be 'forced to be free'. Freedom does not lie in an ideal or principle, let alone in a particular community or form of society. Freedom lies only in oneself, and is not conditional upon living up to some idealised form of humanity, as the humanists and republicans of Stirner's time proclaimed. There is nothing to be achieved, no goal to be attained, no ideal to be lived up to, no teleological end to be pursued. Rather, freedom is our ontological condition. Stirner's warning about possessedness is simply to make us aware of those internal drives that threaten this ontological freedom, so that we can better guard against them.

\section{Ontological freedom and egoistic self-constitution}

This crucial distinction between ownness and positive freedom may be further clarified if we consider how Stirner understands subjectivity. Who or what precisely is the egoist or owner? 
We must be clear that when Stirner talks about the owner or individual egoist, he is referring not to a particular type of person and he is not in any sense setting out to establish an essential form of subjectivity that we should copy or aspire to. The egoist is not a fixed or idealised subject with essential properties and characteristics - like the self-interested individual in liberalism, or the citizen in republicanism, or even the authentic self invoked in the concept of positive freedom - but rather an open, self-constituting immanence. The egoist or owner is always in flux, always becoming, always consuming himself and inventing himself anew. The egoist is a subject without presuppositions, without a fixed identity or destiny:

I do not presuppose myself, because I am every moment just positing or creating myself, and am I only by being not presupposed but posited, and, again, posited only in the moment when I posit myself; that is, I am creator and creature [Schöpfer und Geschöpf] in one (Stirner 1995: 135)

This unfixity of the subject is how we should understand ontological freedom; the subject is a ‘creative nothing' (7), free to constitute herself as she chooses, without being encumbered by any sort of moral ideal or rational telos, or even any notion of an essential identity which defines for her certain characteristics or properties that are immutable. Quite simply, the subject cannot be pinned down to any specific category or identity, but evades these in an ongoing process of self-constitution. While this would appear to bear some resemblance to existentialism, Stirner's rejection of the idea of an authentic self - as we discussed in the previous section - means that his conception of freedom as ownness cannot adequately be described as existentialist, despite his influence on that tradition (see Clark 1971). As Douglas Moggach puts it, ownness means simply to be the 'sufficient cause of one's own representations and actions' (2009 71). So, we should not think of freedom as an object to be attained or a goal to be achieved, but rather as an ontologically anarchic space of 
subjectification $^{11}$, which gives the subject the freedom to define her own singular path, or paths, of freedom. Ownness, then, might be understood as a way, as Foucault said, of not discovering who we are but refusing who we are. In other words, it might be seen as a strategy of freeing oneself from the forms of subjectivity that have been imposed upon us by contemporary forms of governmentality.

\section{Conclusion}

My claim has been that existing approaches to freedom are insufficient to critically respond to the ways in which freedom has been deployed today by neoliberal governmentality, and that it is only by rethinking freedom at its ontological level that we are able to retrieve it from the forms of subjectification that currently render it impotent. Put simply, we need to fundamentally reconsider what the 'free subject' means today. I have argued that Stirner's concept of ownness - as difficult as it is to define it within existing normative and conceptual frameworks - offers us a way of rethinking freedom as independent of external conditions and as the ontological condition of the subject as such. In this paper I have sought to explore the contours of this somewhat ambiguous concept by showing how it departs from more recognised paradigms of negative, republican and positive freedom. I have interpreted ownness - with its related notions of egoism and property - primarily as a form of selfaffirmation or self-possession, which not only ontologically precedes other forms of freedom but which acts as the well-spring of resistance. In freeing freedom from determination by external institutions, the limiting action of others, and even from itself as an 'overall concept' or universal normative ideal, Stirner has shown how freedom might be returned to the self and experienced as an anarchic and singular space of self-constitution.

\section{Bibliography}


Bakunin, M., 1971. Bakunin on Anarchy, ed., and trans., Sam Dolgoff, New York: Vintage Books.

Bellamy, R. (2011) Republicanism: Non Domination and the Free State. In: G. Delanty and S.P Turner, Routledge International Handbook of Contemporary Social and Political Theory, Abingdon, Oxon: Routledge, 130-138.

Berlin, I., 1969. Four Essays on Liberty, Oxford: Oxford University Press.

Brown, W., 2015. Undoing the Demos: Neoliberalism's Stealth Revolution, New York: Zone Books.

Carroll, J., 1974. Break-Out form the Crystal Palace. The anarcho-psychological critique: Stirner, Nietzsche, Dostoyevsky, London: Routledge and Kegan Paul.

Carter, I. 1999. A Measure of Freedom, Oxford: Oxford University Press.

Clark, J. P. 1976. Max Stirner's Egoism, London: Freedom Press.

Connolly, W. E (1993) The Terms of Political Discourse, Oxford: Blackwell.

De Ridder, W., 2008. Max Stirner, Hegel and the Young Hegelians: a critical reassessment. History of European Ideas 34:3, 285-297.

Dworkin, R. (1979) ‘We Do Not Have a Right to Liberty’ http://homepage.westmont.edu/hoeckley/readings/Symposium/PDF/301_400/312.pdf (accessed 20 July 2016)

Flathman, R. E., 2003. Freedom and its Conditions: Discipline, Autonomy and Resistance, New York: Routledge.

Foucault, M., 1980. Powers and Strategies (Interview with Michel Foucault). In: C. Gordon ed., Power/Knowledge: Selected Interviews and Other Writings 1972-1977, ed., New York: Pantheon Books, 134-145.

Foucault, M., 2005. The Hermeneutics of the Subject. Lectures at the Collège de France, 
1981-2, ed., Frédéric Gros, trans., Graham Burchell. Houndmills, Basingstoke: Palgrave Macmillan.

Foucault, M., 2010. The Birth of Biopolitics: lectures at the College de France, 19781979, ed., Michel Senellart; trans., Graham Burchell. New York: Palgrave Macmillan. Godwin, W., 1985. Enquiry Concerning Political Justice, Harmondsworth: Penguin. Jenkins, J. 2009. ‘Max Stirner’s Egoism’, The Heythrop Journal, 50: 2, 243-256.

Kinna, R. and Prichard, A., 2012. Anarchism and Non-Domination. Unpublished paper, delivered at the $2^{\text {nd }}$ Anarchist Studies conference in 2012 (cited with permission from the authors).

Kramer, M. H. (2003) The Quality of Freedom, Oxford: Oxford University Press.

Kramer, M. H (2008) Liberty and Domination. In: C. Laborde and J. Maynor eds., Republicanism and Political Theory, Oxford: Blackwell, 31-57.

Laborde, C. and Maynor, J., 2008. The Republican Contribution to Contemporary Political Theory. In: C. Laborde and J. Maynor eds., Republicanism and Political Theory, Oxford: Blackwell, 1-29.

Locke, J. 1988. Two Treaties of Government, ed., P. Laslett, Cambridge: Cambridge University Press.

MacCallum, G. C. Jr. 2006, Negative and Positive Liberty. In: D. Miller ed., Liberty, Oxford: Oxford University Press, 100-122.

Marshall, P. 2008. Demanding the Impossible: a History of Anarchism, London, New York: Harper Perennial.

Marx, K. and Engels, F. (1932) The German Ideology. The Collected Works. Volume 5 < https://www.marxists.org/archive/marx/works/1845/german-ideology/> (accessed 29 June 2016).

Moggach, D., 2003. The Philosophy and Politics of Bruno Bauer, Cambridge: Cambridge 
University Press.

Paterson, R.W.K. 1971. Nihilistic Egoist: Max Stirner, Oxford: Oxford University Press.

Pettit, P., 1997. Republicanism: a Theory of Freedom and Government, Oxford: Oxford University Press.

Proudhon, P-J. 1993. What is Property?, ed., D. R Kelly and B. G. Smith, Cambridge: Cambridge University Press.

Schmitt, M. and Van der Walt, L. 2009. Black Flame: the Revolutionary Class Politics of Anarchism and Syndicalism, Vol. 1. Oakland, CA.: AK Press.

Schürmann, R.1986. 'On Constituting Oneself an Anarchist Subject', Praxis International, 6:3, 294-310.

Schürmann, R., 1987. Heidegger on Being and Acting: From Principles to Anarchy, trans. C.-M. Gros, Bloomington: Indiana University Press.

Skinner, Q., 1998. Liberty before Liberalism, Cambridge: Cambridge University Press.

Slaughter, S. 2005. Liberty Beyond Neo-liberalism: a Republican Critique of Liberal Governance in a Globalising Age, Houndmills, Basingstoke: Palgrave Macmillan.

Steiner, H., 2006. Individual Liberty. In: D. Miller ed., Liberty, Oxford: Oxford University Press, 123-140.

Stirner, M., 1995. The Ego and Its Own, ed., David Leopold, Cambridge: Cambridge University Press.

Taylor, C. 2006. What's wrong with Negative Liberty? In: D. Miller ed., Liberty, Oxford: Oxford University Press, 141-162.

Welsh, J. F., 2010. Max Stirner's Dialectical Egoism: a new interpretation, Lanham, MD.: Rowman \& Littlefield. 
${ }^{1}$ This is in contrast to those like Dworkin (see 1979) who argue that there is no such thing as freedom as such, only freedom to specific things.

${ }^{2}$ See Kramer's distinction between normative and non-normative or conceptual approaches to freedom (2003: 4-5)

${ }^{3}$ Indeed Steven Slaughter has proposed the idea of a global civic republicanism as a way of retrieving the civic space of the state and protecting individual liberty against the neoliberal globalisation (see 2005).

${ }^{4}$ Although Hillel Steiner, as a proponent of a rather stark form of negative liberty, would insist that even in situations of physical constraint, there is always some degree of freedom (see 2006: 123-140).

${ }^{5}$ Stirner's place within the anarchist canon is somewhat controversial. For many, his egoistic individualism sits only very uneasily with the more collectivist and socialist traditions of anarchism (see Paterson 1971; Clark 1976). Indeed, according to Schmitt and van der Walt, Stirner’s ‘extreme individualism’ places him outside the anarchist tradition altogether (2009: 36).

${ }^{6}$ However, Stirner might say, in contrast to Godwin, that where a command happens to coincide with one's will, while not in itself legitimate, it might be advantageous to comply with it: in other words, there is no moral duty to disobey laws.

${ }^{7}$ Amongst these, they list Uri Gordon, Sam Clark and Saul Newman (see 2012).

${ }^{8}$ While Stirner's radical individualism would appear to preclude any communal understanding of freedom or even any possibility of politics at all, his somewhat paradoxical figure of the 'union of egoists' (see 160-161), which is opposed to all predetermined forms of society, allows for collective action, as long as this is formed purely for the egoistic interests of its members and requires no sacrifice of the individual. 
${ }^{9}$ Stirner's ontological and ethical egoism must also be distinguished a cruder psychological egoism, according to which some commentators interpret his philosophy (see Jenkins 2009: 243-256). Stirner points to the existence of non-egoistic actions and forms of behavior, and suggests that there are competing drives within the individual, not all of which are driven by self-interest. Indeed, we might, with greater accuracy, refer to Stirner’s 'anarchopsychology': a concern to help the individual free himself from the ideological structures and 'spooks' which he has internalized within his psyche and which get in the way of his selfinterest (see Carroll 1974).

${ }^{10}$ Indeed Foucault lists Stirner as one of the nineteenth century thinkers - along with Baudelaire, Schopenhauer and Nietzsche - who were engaged in an experimentation with an ethics and aesthetics of the self (2005: 251).

${ }^{11}$ I borrow this concept in part from Reiner Schürmann (see 1986; 1987). 